\title{
Sled for Sampling Benthic Fish Larvae
}

Traditional sampling gear for plankton and benthos proved to be inadequate for collection of demersal fish larvae from the inshore waters of southeastern lake Michigan. Conical plankton nets $(0.5 \mathrm{~m}$ in diameter did not effectively sample near-bottom (within $0.5 \mathrm{~m}$ ) water. Plankton rets mounted on sleds have been used to collect epibenthic plankton; Calhoun (1953) was one of the first to sample fish larvae with a sled, and Chad. wick (1964) and Dovel (1964) used sleds to collect es. tuarine macroplankton. Incorporating features of a macrobenthos sled developed at Great Lakes Research Division, we evolved a sled design of simple construction and light weight, that was easy to handle and protected sample jars from breakage. Our design alleviated nearbottom sampling problems associated with conical plankton nets and enabled capture of demersal and shal. low-water fish larvae. We later learned that a similar sled had been developed by Tupp (1967).

We required a sled that would be easy to handle in shallow water or from a small boat, that would incorpo. rate an existing nylon plankton ret $0.5 \mathrm{~m}$ in diameter. and that would position the net mouth near the bottum. for elficient filtering. A lightweight, negatively buoyant frame was construeted from aluminum tubing with $19-\mathrm{mm}(0.75 \mathrm{in}$. nominal) $O D$ and $3.2 \cdot \mathrm{mm}(0.13 \mathrm{in}$. nominal) wall thickness connected with proprietary, cast aluminum sleeve-type rail fittings (Fig. 1 . The sled consisted of two rectangular frames connecting a pair of runners and a pair of upper longitudinal stringers. A crosspiece in front of the forward frame provided stiffen. ing and an attachment point for a bottom tickler. Two ropes tied to the towing bridle enabled us to pull the sled without walking directiy in front of it.

Because large quantities of sand were trapped in the $0.5-m m$ diameter $(0.36-\mathrm{mm}$ aperture) net when the net mouth was within $2.5 \mathrm{~cm}$ of the lake bottom, we constructed a rectangular net frame $20 \times 57.5 \mathrm{~cm}$ from stainiess steel tubing, laced the plankton net to the net irame, and suspended it from the forward sled frame by small coil springs attached to each corter (Fig. 1). This arrangement held the net mouth $5 \mathrm{~cm}$ above lake bottom and eliminated the sand-trapping problem. A Nowmeter mounted in the center of the frame enabled quantification of sample volume.

A large plastic bottle tied with twine to the back frame (Fig. 1) positioned the collecting bucket (widemouth Mason jar' and protected it from breakage. After rinsing the contents of the net into the jar, the jar was removed from the net, cach sample was formalinized, and the jar was labeled and capped. Samples were collected at a
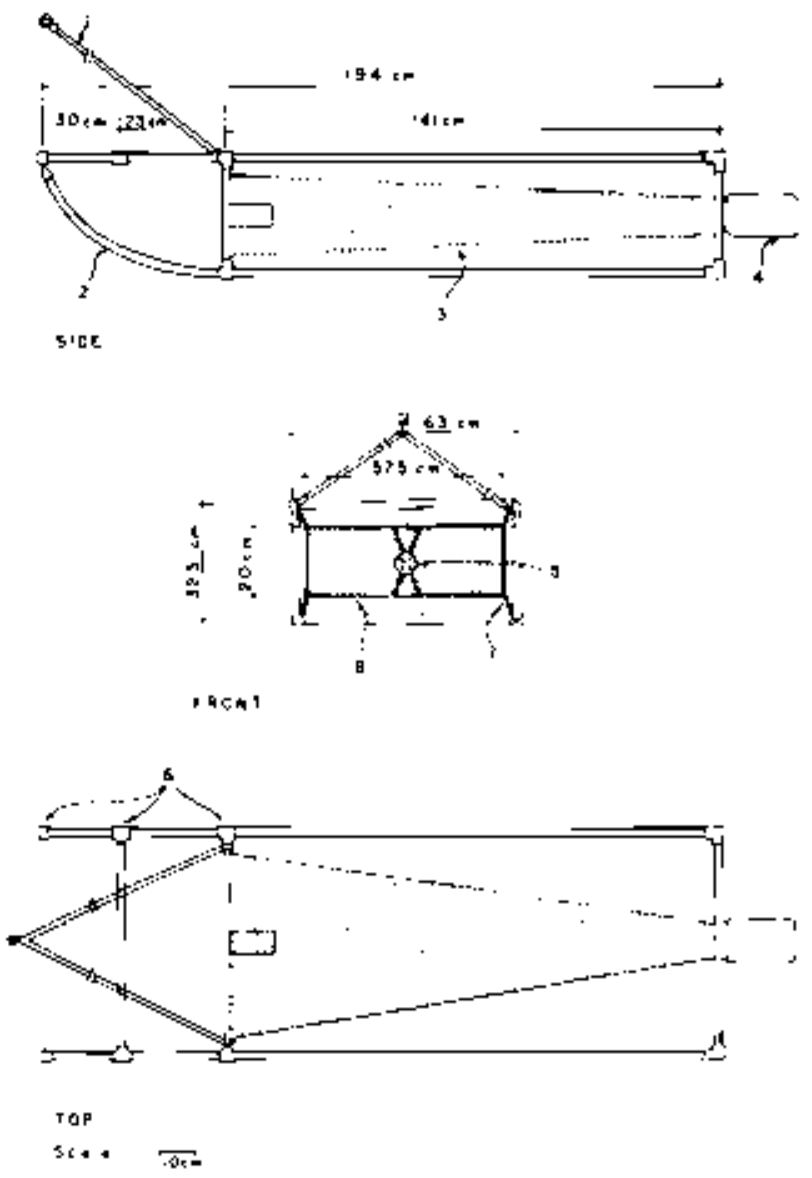

Fig. I. Sipd for rollerting benthic fish tarue and eggk. 1, touing bridle: 2 , runner; 3, plankton net; 4, plastic buttle; 5 , foumeter in rigid motent; 6 , rail fittings; 7 , coil spring; and 8, rectongular net frame.

depth of $1 \mathrm{~m}$ about $25 \mathrm{~m}$ from the shore of southeastern Lake Michigan near the Donald C. Cook Nuclear Plent, about $17 \mathrm{~km}$ south of the mouth of the St. Joseph River. Along the southeastern shore surficial sediments are fine to coarse sand, typical of sand dune beaches (Scibel et al. 1974\%,

The light weight of the sled for benthic fish larvae enabled us to tow it by hand or from a small boat. Lon. gitudinal and lateral stability of the sled kept the mouth of the net oriented near bottom for fishing efficjency. At depths of 6 and $9 \mathrm{~m}$ a towing line ratio of $1: 5$ (depth:length) was necessary. 
The sled collected larval alewives (Alosa pseudoharenguss) and spottail shiners (Notropis hudsonits) as did plankton nets, but generally, mare alewife larvae were caught by plankton nets and more spottail shiners by the sled iTable 1). We believe these catch differences can be attributed to the behavior of these two larval species and to sampling gear characteristics.

Plankton-net samples from shallow and dcep stations (dude et al. 1975) revealed that alewives were distrib. uted throughout the water column, and plankton nets alone could be used to estimate the abundance of larval alewives in the inshore waters of southeastern Lake Michigan.

Samples collected with plankton nets in 1973 showed few spottail shiner larvae, although many ripe adult spottail shiners were caught in beach seines iJude et al. 1975) and scuba divers observed spawning spottail shin. ers in the area (Dorr 1974). Plankton-net collections in 1974 were again smald, but sled collections contained many spottail shiner larvae, corfirming their demersal habit and inshore abundance.

Fish eggs (not identified, but presumably predomi nantly alewife and spottail shiner eggs) were consistently collected in greater numbers by the sled than by plankton nets (Table 1 ).

Table 1. Number (per $10 \mathrm{~m}^{3}$ of water) of alewife and spottail shiner tareae and fish eggs collected by duplicate plankton-net tows and single benthic-sled tows from a shallou $\mathrm{t} / \mathrm{m}$ ) beach station in southeastern Lake Michigan during summer 1974. Gears were touled by wading parallel to shore for about $60 \mathrm{~m}$; the plankton net was held just under the water surface and the sted was dragged on the bottom.

\begin{tabular}{|c|c|c|c|}
\hline \multirow{2}{*}{ Date and method } & \multicolumn{2}{|c|}{ Species } & \multirow[b]{2}{*}{$\begin{array}{c}\text { Fish egk } \\
\text { (No.) }\end{array}$} \\
\hline & Alewife & $\begin{array}{l}\text { Spottail } \\
\text { shiner }\end{array}$ & \\
\hline \multicolumn{4}{|l|}{11 dune } \\
\hline Planktor net & 57 & 2 & $\begin{array}{l}1,240 \\
1,500\end{array}$ \\
\hline Benthic sled & 43 & 4 & 118,000 \\
\hline \multicolumn{4}{|l|}{$11 \mathrm{July}$} \\
\hline Planklon net & 25 & 12 & 3 \\
\hline Plankton net & 3 & 32 & d \\
\hline Benthic sled & 8 & 125 & 247 \\
\hline \multicolumn{4}{|l|}{5 August } \\
\hline Plankton ret & 8 & 0 & 0 \\
\hline Plankton ret & g & 2 & 2 \\
\hline Benthic slẹd & 2 & 11 & $\$ 2$ \\
\hline \multicolumn{4}{|l|}{ 14 August } \\
\hline Plankton net & 8 & 0 & 3 \\
\hline Planktor net & 12 & 0 & 4 \\
\hline Benthic sled & $\eta$ & 1 & 6 \\
\hline
\end{tabular}

Results of sampling with plankton rets may indicate which larval fish species are present in lakes and large rivers, but abundance estimates for demersal species may be low. The use of a sled may provide more reliable abundance estimates of demersal species and of fish eggs.

\section{Acknowledgments}

This research was supported by the Indians and Michigan Electric Company through funds granted to John $C$. Ayers for research on Lake Michigan in the vicinity of the Donald C. Cook Nuclear Plant. We thank Devid J. Jude and John C. Ayers for reviewing the manuscript and John Dorr, Timothy Miller, Nancy Thurber, and Paul Rago for their efforts in the field and laboratory. This report is Contribution No. 265 of the Great Lakes Research Division, University of Michigan.

\section{References}

Calhoun, A.J. 1953. Distribution of striped bass fry in relation to major water diversions. Colif, Fish Game 39:279-299.

Chadwick. H.K. 1964. Ansual ahundance of young striped bass, Rocrus saxatitis, in the Sacramenta-San Jaaquin Deita, Calitornia. Calif. Fish Genne 50:69-99.

Dorr. J.A.. III. 1974. Underwater operations in southeastern Lake Michigan near the Donald C. Cook Power Plant during 1373. Poges 465-475 in E. Sejbel and J.C. Ayers, eds. The hiological, chemical, and physical character of Lake Michi. gan in the viririty of the Donald C. Conk Nucleas Plant. Spex. Rep 51. Greal Lakes Res. Diy., University of Michigan, Ann Arbor.

Davel. W.L. 1964. An approach to sampling estuarıne macroplankion. Chesapeake Sci. 5:77-00.

Jude, D.J., F.J. Teser, J.A. Darr, IIl, T.J. MiJler, P.J. Rago, and D J. Stewart. 1975. Inshore Lake Michigan Iish populations nesr the D.C. Cook Nuclear Power Plant, 1973. Spec. Kep. 52. Great Lakes Res. Div., Unjversity of Michigan, Ann Arbor. $267 \mathrm{pp}$.

Sejbel, E., R.E. Jenser, and C.T. Carlsan. 1974. Surficial sedifnent distribution of the nearshort waters in suutheastern Lake Michigan. Pages 369.432 in E. Sejbel and J.C. Ayers. eds. The biological, chemical. and physical character of Lake Michigan in the vicinity of the Donald C. Cook Nucless Plant. Spec. Rep. 51. Great Lapkes Res. Div., Liniversity of Michigan, Ann Arbor.

Topp. R.W. 1967. Ar adjustable macroplankton sled. ProkFish.Cult. 29(3): 184.

- William L. Yocum and Frank J. Tesar, Great Lakes Restarch Divisitu, University of Mithigan, Ann Artor, 48109.

Accepted 28 Noumber 1979 